\title{
Antithrombin Activity Measurement
}

National Cancer Institute

\section{Source}

National Cancer Institute. Antithrombin Activity Measurement. NCI Thesaurus. Code C81958.

The determination of the amount of antithrombin activity in a sample. 